Faras Mentari ${ }^{1}$ Daviq Chairilsyah $^{2}$ Zulkifli $^{3}$

\section{PERBEDAAN KEMAMPUAN BAHASA ANAK USIA 4-5 TAHUN YANG DIASUH OLEH ORANG TUA KANDUNG DENGAN ANAK YANG DIASUH OLEH SELAIN ORANG TUA KANDUNG DI KOTA BUKITTINGGI}

\begin{abstract}
Abstrak
Masalah dalam penelitian ini adalah dikota Bukittinggi yang memiliki 23.416 keluarga (data dari bukittinggikota.go.id) masih banyak orang tua yang mengalihkan pengasuhan terhadap anak kepada orang lain seperti saudara, nenek, kakek, dan sebagainya dikarenakan beberapa faktor seperti faktor ekonomi yang mengharuskan orang tua anak bekerja diluar rumah seharian. Teknik pengambilan sampel yaitu simple random Sampling dan pengumpulan data menggunakan kuesioner/angket. Berdasarkan analisis pengolahan data hasil kemampuan bahasa anak usia 4-5 Tahun yang diasuh oleh orang tua kandung di Kota Bukittinggi diperoleh jumlah nilai 466 dengan rata-rata persentase $77,67 \%$ berada pada kriteria berkembang sangat baik (BSB). Dan hasil kemampuan bahasa anak usia 4-5 Tahun yang diasuh oleh selain orang tua kandung di Kota Bukittinggi diperoleh jumlah nilai 448 dengan rata-rata persentase $74,67 \%$ berda pada kriteria berkembang sesuai harapan (BSH). Berdasarkan hasil hipotesis dapat diketahui bahwa kemampuan bahasa anak usia 4-5 tahun yang diasuh oleh orang tua kandung lebih baik dibandingkan anak yang diasuh oleh selain orang tua kandung di Kota Bukittinggi.
\end{abstract}

Kata Kunci: Kemampuan Bahasa, Anak yang diasuh oleh Orang Tua Kandung, Anak yang Diasuh oleh Selain Orang Tua Kandung

\title{
Abstract
}

The case in this study was in Bukittinggi city which has 23,416 families (data from bukittinggikota.go.id), there are still many parents who divert parenting to others such as siblings, grandmothers, grandfathers, and so on due to several factors such as economic factor that require the child's parents to work outdoors all day. The sampling technique used simple random sampling and the data collection used questionnaire method. Based on data processing analysis, the results of children's language ability aged 4-5 years old who were cared for by biological parents in Bukittinggi obtained the number of values 466 with the average percentage of $77,67 \%$ being on the criteria of developing very well (BSB). And the results of children's language ability aged 4-5 years old who were cared for in addition to their biological parents in Bukittinggi obtained the number of values 448 with the average percentage of $74.67 \%$ being on the criteria of developing according to expectations (BSH). Based on the results of the hypothesis, it could be seen that the children's language ability who were cared for by biological parents were better than children who were cared for in addition to their biological parents in Bukittinggi.

Keywords: Language Ability ,Children's Cared for by Biological Parents, Children's Cared for in Addition to Their Biological Parents

\footnotetext{
1,2,3) Program Studi Pendidikan Guru Pendidikan Anak Usia Dini, Fakultas Keguruan dan Ilmu Pendidikan, Universitas Riau

${ }^{1)}$ Alamat email Farasmentari@gmail.com
} 


\section{PENDAHULUAN}

Anak usia dini merupakan sesorang yang berada pada proses pertumbuhan dan perkembangan yang bersifat unik. Mereka mempunyai pola pertumbuhan dan perkembangan yang khusus sesuai dengan tingkat pertumbuhan dan perkembangannya masing masing (Mansur, 2005)

Pada masa ini merupakan masa emas (golden age), masa ini merupakan masa yang penting dalam perkembangannya karena mengalami pertumbuhan dan perkembangan yang cukup cepat dan tidak tergantikan pada masa yang akan datang. Berdasarkan penelitian dalam bidang neurologi dijelaskan bahwa 50\% kecerdasan anak terbentuk pada kurun 4 tahun pertama. Setelah usia 8 tahun, perkembangan otak anak bisa mencapai hingga $80 \%$ pada usia 18 tahun mencapai $100 \%$ (Suyanto, 2005).

Berdasarkan Undang-undang Sisdiknas tahun 2003 pasal 1 ayat 14, pembinaan yang ditujukan untuk anak usia 0-6 tahun tersebut dilakukan melalui Pendidikan Anak Usia Dini (PAUD). Pendidikan anak usia dini dapat dilaksanakan dengan pendidikan formal, nonformal dan informal. Pendidikan anak usia dini jalur formal, taman kanak-kanak (TK) dan Raudatul Athfal (RA) dan bentuk lain yang sederajat.

Mengacu pada undang-undang Nomor 20 tahun 2003 tentang Sistem Pendidikan Nasional berkaitan dengan Pendidikan Anak Usia Dini tertulis pada pasal 28 ayat 1 yang berbunyi "Pendidikan Anak Usia Dini diselenggarakan untuk anak sejak lahir hingga 6 tahun dan bukan merupakan prasyarat untuk mengikuti pendidikan dasar". Selanjutnya pada Bab 1 ayat 14 dijelaskan bahwa Pendidikan Anak Usia Dini adalah suatu upaya pembinaan yang ditunjukkan bagi anak sejak lahir sampai dengan usia 6 tahun yang dilakukan melalui pemberian rangsangan pendidikan untuk membantu pertumbuhan dan perkembangan jasmani dan rohani agar anak memiliki kesiapan dalam memasuki pendidikan lebih lanjut (Depdiknas, USPN, 2004). Pendidikan Anak Usia Dini merupakan salah satu bentuk pelaksanaa pendidikan yang berguna untuk pertumbuhan dan perkembangan fisik (koordinasi motorik halus dan kasar), kecerdasan sosio emosional), bahasa dan komunikasi, sesuai dengan keunikan dan tahap perkembangan yang dilalui oleh anak usia dini.Dalam kemampuan berbahasa, anak mampu memberikan mengikuti perintah, dan memberi respon terhadap suara serta berbicara secara spontan (Soetjiningsih \& Ranuh, 2014).

Pendidikan mempunyai peran penting dalam menentukan perkembangan, salah satunya perkembangan bahasa. Dalam mengembangkan bahasa, orang dewasa dituntut untuk menuturkan perkataan yang baik terhadap anak. Piaget menjelaskan bahwa perkembangan bahasa secara keseluruhan sebagai hasil interaksi anak dengan lingkungan dan juga kemampuan kognitif dan pengalaman bahasa. Vygotsky menjelaskan bahwa pembelajaran bahasa terjadi melalui interaksi sehari-hari dan berbagi pengalaman antara orang dewasa dan anak. Vygotsky juga menjelaskan bawhabahasa memiliki beberapa peran salah satu yang mentransfer konsepkonsep abstrak dan penalaran logis. Selain itu peran lain dari bahasa adalah adanya pembentukan komunikasi melalui interaksi sosial yang dapat dianggap sebagai faktor kontribusi utama perkembangan bahasa anak usia dini.Bromley menjelaskan bahwa bahasa merupakan sistem simbol yang teratur untuk mentransfer berbagai ide maupun informasi yang terdiri atas simbol visual maupun verbal. Simbol visual dapat dilihat, ditulis dan dibaca, dan symbol verbal dapat diucapkan dan didengar.

Bahasa adalah alat komunikasi yang utama dalam kehidupan manusia. Pada umumnya seluruh aktivitas manusia membutuhkan alat komunikasi untuk berinteraksi dengan lingkungan sekitarnya. Bahasa yang digunakan sebagai alat komunikasi tidak hanya digunakan oleh orang dewasa. Anak usia dini bahkan bayi pun juga menggunakan bahasa sebagai alat utama untuk berkomunikasi. Menangis merupakan salah satu cara bayi untuk berkomunikasi dengan lingkungan sekitarnya (Chaer, 2009). Menangis juga dapat diidentifikasi sebagai bahasa, yaitu bahasa yang pertama kalinya oleh bayiyang digunakan untuk menyampaikan apa yang diinginkannya.

Seiring dengan bertambahnya usia anak, bahasa anak pun akan semakin berkembang pula. Perkembangan bahasa anak dapat diperoleh melalui proses pembelajaran bahasa. Pembelajaran bahasa (language learning) berkaitan dengan proses-proses yang terjadi pada waktu seorang kanak-kanak mempelajari bahasa kedua, setelah memperoleh bahasa 
pertamanya (Chaer, 2009). Artinya, proses pembelajaran bahasa didahului dengan proses pemerolehan bahasa pertamanya atau bahasa ibunya.

Semua manusia dapat menguasai bahasa, karena sejak lahir manusia telah memiliki kemampuan dan kesiapan untuk mempelajari bahasa dengan sendirinya. Kemampuan berbahasa terdiri dari pemahaman bahasa terlebih dahulu harus dikembangkan sebelum mengembangkan kemampuan bicara yang merupakan salah satu media untuk menyampaikan pesan dalam wujud bahasa lisan.

Pada masa awal, bahasa anak-anak bersifat egosentris, yaitu bentuk bahasa yang lebih menonjolkan diri sendiri, berkisar pada minat, keluarga, dan miliknyasendiri. Menjelang akhir masa anak-anak awal percakapan anak-anak berangsur- angsur berkembang menjadi bahasa sosial.Menurut pendapat para pakar di atas dapat penulis simpulkan bahwa perkembangan bahasa bagi anak adalah proses kemampuan memahami dan mengungkapkan suatu keadaan tertentu sehingga dapat berkembang menjadi suatu alat yang digunakan untuk berinteraksi dengan orang lain.

Perkembangan bahasa anak dapat dipengaruhi oleh beberapa faktor diantaranya interaksi orang tua dengan anak serta pola asuh didalamnya merupakan faktor paling penting dalam proses tumbuh kembang anak. Oleh karena itu, sangat diperlukan stimulus yang baik dan sesuai kebutuhan anak. Stimulus tersebut dapat dilakukan ole orang tua ataupun selain orang tua dalam mempengaruhi perkembangan bahasa anak. Kemampuan bahasa anak dapat diketahui melalui kuesioner tentang perkembangan bahasa anak usia 4-5 tahun.

Dalam penelitian mengenai perkembangan bahasa anak, penulis ingin memfokuskan kemampuan bahasa anak usia 4-5 tahun.

Perkembangan bahasa anak diawali dari menyimak, dari menyimak akan berdampak pada keterampilan berbicara. Kemudian apakah ada perbedaan perkembangan bahasa antara anak yang diasuh oleh orang tuanya sendiri dengan anak yang di asuh oleh selain orangtua kandung? Anak yang diasuh oleh orang tuanya sendiri perkembangan bahasa anak lebih baik dari pada anak yng diasuh oleh selain orang tua kandung. Aspek yang mempengaruhi perkembangan bahasa anak:

1. Kosa kata setiap anak lambat laun anak berkembang melalui interaksi dengan lingkungannya.

2. Sintaksis, tata bahasa dalam aspek ini meskipun anak belum diajari tapi si anak mampu memahaminya melalui interaksi dengan lingkungan.

3. Semantik, dalm aspek ini anak sudah dapat mengekspresikan keinginan dan penolakannya tanpa didasari faktor orang lain

4. Fenom, anak sudah mampu merangkaikan bunyi yang bisa di dengar menjadi suku kata yang bermakna.

Menurut Fadillah (2012) mengatakan bahwa segala tingkah laku maupun perkembangan pada diri anak akan mencontoh pada kedua orang tua. Menurut penelitian yang dilakukan oleh Yektiningsih (2010) yang menunjukkan bahwa terdapat hubungan yang sangat erat antara pemberian stimulasi oleh orang tua dengan perkembangan bahasa anak usia prasekolah di TK Al Fath Pare daripada stimulasi oleh orang lain. Ini dikarenakan adanya faktor kelekatan.

Menurut Puji (2008), sesungguhnya pendidikan yang utama dan pertama bagi anak usia dini berada dirumah bersama orang tua (ayah dan ibu). Indikator nya adalah orang tua (ayah dan ibu) merupakan orang yang paling bertanggung jawab terhadap perkembangan anak-anaknya sebelum mereka berinteraksi dengan orang lain. Akan tetapi, dikota Bukittinggi yang memiliki 23.416 keluarga (data dari bukittinggikota.go.id) masih banyak orang tua yang mengalihkan pengasuhan terhadap anak kepada orang lain seperti saudara, nenek, kakek, dan sebagainya dikarenakan beberapa faktor seperti faktor ekonomi yang mengharuskan orang tua anak bekerja diluar rumah seharian.

Berdasarkan uraian diatas, mendorong peneliti untuk mengangkat judul penelitian "Perbedaan kemampuan bahasa anak usia 4-5 tahun yang diasuh oleh orang tua kandung dengan anak yang diasuh oleh selain orang tua kandung 


\section{METODE}

Penelitian ini dapat dikategorikan sebagai penelitian komparatif dalam pemilihan menggunakan teknik simple random sampling. Pengumpulan data dengan menggunakan kuesioner/angket.

Penelitian ini adalah penelitian kuantitatif dengan jenis penelitian komparatif yang bersifat Expost Facto menurut Kerlinger (dalam Sudaryono, 2016) mendefinisikan expost facto sebagai pencarian empirik yang sistematis dalam ilmuwan tidak dapat mengontrol langsung variabel bebas karena peristiwanya telah terjadi atau karena menurut sifatnya tidak bisa dimanipulasi. Metode penelitian kuantitatif adalah penelitian yang berlandaskan pada filsafat positivisme, digunakan untuk meneliti pada populasi atau sampel tertentu, teknik pengambilan sampel pada umumnya dilakukan secara acak, pengumpulan databertujuan untuk menguji hipotesis yang telah ditetapkan (Sugiyono akan instrumen penelitian analisis data bersifat kuantitatif atau statistic, 2016). Penelitian ini akan mencari tahu perbedaan antara variabel satu dengan variabel lain.

Penelitian ini dilakukan secara online dengan menyebarkan angket untuk diisi oleh responden yaitu orang tua/wali murid dan guru wali kelas secara online. Waktu penelitian dilaksanakan pada bulan April-Mei 2020. Populasi adalah wilayah generalisasi yang terdiri atas objek atau subjek yang mempunyai kualitas dan karakteristik yang ditetapkan oleh peneliti untuk dipelajari dan kemudian ditarik kesimpulan (Sugiyono,2010). Menurut Suharsimi Arikunto (2010) populasi adalah wilayah keseluruhan subjek atau objek penelitian. Jadi populasi dalam penelitian ini adalah anak usia 4-5 tahun diKota Bukittinggi. Sampel adalah bagian dari jumlah dan karakteristik yang dimiliki oleh populasi (Darmadi, 2013). Sampel yang digunakan untuk penelitian ni yaitu menggunakan simple random sampling.

\section{HASIL DAN PEMBAHASAN}

A. Hasil Penelitian

1. Gambaran Umum Kemampuan Bahasa Anak Usia 4-5 Tahun yang Diasuh Oleh Orang Tua Kandung di Kota Bukittinggi.

Berdasarkan hasil kuesioner dapat dilihat bahwa kemampuan bahasa anak usia 4-5 tahun yang diasuh oleh orang tua kandung di Kota Bukittinggi dapat dilihat pada tabel berikut ini:

Tabel 1. Gambaran Umum Kemampuan Bahasa Anak Usia 4-5 Tahun yang Diasuh Oleh Orang Tua Kandung di Kota Bukittinggi.

\begin{tabular}{cccccc} 
No & Indikator & Skor Akhir & Skor Ideal & Persentase & Kriteria \\
\hline 1 & 99 & 120 & 82.50 & BSB \\
2 & 93 & 120 & 77.50 & BSB \\
3 & 101 & 120 & 84.17 & BSB \\
4 & 94 & 120 & 78.33 & BSB \\
5 & 94 & 120 & 78.33 & BSB \\
\hline Jumlah & 481 & 2160 & & \\
\hline Rata-rata & 96.20 & 120 & 80.17 & BSB \\
\hline
\end{tabular}

Sumber: olahan data penelitian 2020

Berdasarkan tabel di atas, dapat diketahui bahwa pada skor akhir tertinggi terdapat pada indikator 3 yaitu anak mampumenyebutkan kata-kata yang dikenaldengan skor 101 persentase $84,17 \%$ berada pada kriteria berkembang sangat baik (BSB). Skor akhir terendah terdapat pada indikator 2 yaitu anak mampu mengungkap perasaan dengan kata sifat (baik, senang, nakal, pelit, baik hati, berani, baik, jelek, dsb)dengan skor 93 persentase $77,50 \%$ berada pada kriteria berkembang sangat baik (BSB).

Berdasarkan hasil perhitungan tabel di atas maka dapat diketahui bahwa persentase pada indikator tersebut yaitu 80,17\% berada pada kriteria berkembang sangat baik (BSB). 
Untuk mengetahui gambaran kemampuan bahasa anak yang diasuh oleh orang tua kandungmaka dapat dilihat pada tabel dibawah ini:

Tabel 2 Kemampuan Bahasa Anak Usia 4-5 Tahun yang Diasuh oleh Orang Tua Kandung di Kota Bukittinggi

\begin{tabular}{ccccc}
\hline No & Kategori & Rentang Skor & Frekuensi & $\%$ \\
\hline 1 & BSB & $76-100 \%$ & 20 & 66.67 \\
2 & BSH & $56-75 \%$ & 10 & 33.33 \\
3 & MB & $41-55 \%$ & 0 & 0 \\
4 & BB & $\leq 40 \%$ & 0 & 0 \\
\hline \multicolumn{2}{c}{ Jumlah } & & 30 & 100 \\
\hline
\end{tabular}

Sumber: Olahan Data Penelitian 2020, Lampiran3 halaman 37

Berdasarkan tabel diatas maka dapat diketahui bahwa kemampuan bahasa anak yang diasuh oleh orang tua kandungdiperoleh data tidak ada anak yang berada pada kriteria belum berkembang (BB) dan mulai berkembang (MB), anak yang berada pada kriteria berkembang sesuai harapan (BSH) sebanyak 10 anak dengan persentase 33,33\% dan anak yang berada pada berkembang sesuai harapan (BSB) sebanyak 20 anak dengan presentase 66,67\%.

2. Gambaran umum kemampuan bahasa anak usia 4-5 tahun yang diasuh oleh selain orang tua kandung

Berdasarkan hasil kuesioner dapat dilihat bahwa kemampuan bahasa anak usia 4-5 tahun yang diasuh oleh orang tua kandung di Kota Bukittinggi dapat dilihat pada tabel berikut ini:

Tabel 3 Kemampuan Bahasa Anak Usia 4-5 Tahun yang Diasuh oleh Selain Orang Tua Kandung di Kota Bukittinggi

\begin{tabular}{cccccc} 
No & Indikator & Skor Akhir & Skor Ideal & Persentase & Kriteria \\
\hline 1 & 89 & 120 & 74.17 & BSH \\
2 & 87 & 120 & 72.50 & BSH \\
3 & & 86 & 120 & 71.67 & BSH \\
4 & 89 & 120 & 74.17 & BSH \\
5 & 91 & 120 & 75.83 & BSB \\
\hline Jumlah & 442 & 2160 & & \\
\hline Rata-rata & 88.40 & 120 & 73.67 & BSH
\end{tabular}

Sumber: Olahan Data Penelitian 2020,

Berdasarkan tabel di atas, dapat diketahui bahwa pada skor akhir tertinggi terdapat pada indikator 9 yaitu anak mampumenambah pembendaharaan kata dengan skor 91 persentase 75,83\% berada pada kriteria berkembang sangat baik (BSB). Skor akhir terendah terdapat pada indikator 3yaitu anak mampu menceritakan cerita yang pernah didengar dengan skor 86 persentase $71,67 \%$ berada pada kriteria berkembang sesuai harapan (BSH).

Berdasarkan hasil perhitungan tabel di atas maka dapat diketahui bahwa persentase pada indikator tersebut yaitu 73,67\% berada pada kriteria berkembang sesuai harapan (BSH).

Untuk mengetahui gambaran kemampuan bahasa anak yang diasuh oleh selain orang tua kandung maka dapat dilihat pada tabel dibawah ini:

Tabel 4 Kemampuan Bahasa Anak Usia 4-5 Tahun yang Diasuh oleh Selain Orang Tua Kandung di Kota Bukittinggi 


\begin{tabular}{ccccc}
\hline No & Kategori & Rentang Skor & Frekuensi & $\%$ \\
\hline 1 & BSB & $76-100 \%$ & 9 & 30 \\
2 & BSH & $56-75 \%$ & 21 & 70 \\
3 & MB & $41-55 \%$ & 0 & 0 \\
4 & BB & $\leq 40 \%$ & 0 & 0 \\
\hline \multicolumn{2}{c}{ Jumlah } & & 30 & 100 \\
\hline
\end{tabular}

Sumber: Olahan Data Penelitian 2020, Lampiran4 halaman 38

Berdasarkan tabel di atas maka dapat diketahui bahwa kemampuan bahasa anak yang diasuh oleh selain orang tua kandung diperoleh data tidak ada anak yang berada pada kriteria belum berkembang (BB) dan mulai berkembang, anak yang berada pada kriteria berkembang sesuai harapan (BSH) 21 anak dengan persentase $70 \%$ dan anak yang berada pada kriteria berkembang sangat baik (BSB) 9 anak dengan persentase $30 \%$.

\section{A. Uji Prasyarat dan Analisis}

\section{Uji Linearitas}

Uji linearitas bertujuan untuk mengetahui apakah data yang dimiliki sesuai dengan garis linear atau tidak (apakah ada hubungan antara variabel hendak dianalisis mengikuti garis lurus atau tidak).

ANOVA Table

Tabel 5 Uji Linearitas

\begin{tabular}{|c|c|c|c|c|c|c|c|}
\hline \multicolumn{8}{|l|}{ ANOVA Table } \\
\hline & & & $\begin{array}{l}\text { Sum of } \\
\text { Squares }\end{array}$ & $d f$ & $\begin{array}{l}\text { Mean } \\
\text { Square }\end{array}$ & $F$ & Sig. \\
\hline \multirow{5}{*}{$\begin{array}{l}\text { KANDUNG } \\
* \quad \text { BUKAN } \\
\text { KANDUNG }\end{array}$} & \multirow[t]{3}{*}{$\begin{array}{l}\text { Between } \\
\text { Groups }\end{array}$} & (Combined & 302.738 & 6 & 50.456 & 1.136 & .373 \\
\hline & & Linearity & 47.891 & 1 & 47.891 & 1.078 & .310 \\
\hline & & \begin{tabular}{|l|} 
Deviation \\
from \\
Linearity
\end{tabular} & 254.847 & 5 & 50.969 & 1.148 & .364 \\
\hline & \multicolumn{2}{|c|}{ Within Groups } & 1021.429 & 23 & 44.410 & & \\
\hline & \multicolumn{2}{|c|}{ Total } & 1324.167 & 29 & & & \\
\hline
\end{tabular}

Sumber: Olahan Data Penelitian 2020, Lampiran 6 halaman 40

Berdasarkan tabel di atas menunjukkan hasil pengujian linearitas data kemampuan bahasa anak yang diasuh oleh orang tua kandung dan anak yang diasuh oleh selain orang tua kandungdiketahui nilai Sig. deviation from linearity sebesar 1,148>0,05. Sehingga dapat disimpulkan bahwa hubungan antara anak yang diasuh oleh orang tua kandung dan anak yang diasuh oleh selain orang tua kandung adalah linear.

\section{Uji Homogenitas}

Pengujian homogenitas dimaksudkan untuk memberikan keyakinan bahwa sekumpulan data yang dimanipulasi dalam serangkaian analisis memang berasal dari populasi yang tidak jauh berbeda keragamannya. Analisis homogenitas dalam pengujian ini menggunakan uji chi-square test dengan bantuan program SPSS versi 23. Kolom yang dilihat pada print out ialah kolom Sig. Jika nilai pada kolom Sig.>0,05 maka Ho diterima. 
Tabel 6 Uji Homogenitas

\begin{tabular}{|l|l|l|l|}
\hline \multicolumn{5}{|l|}{ Test of Homogeneity of Variances } \\
\hline \multicolumn{5}{|l|}{ Levene Statistic } & $d f 1$ & $d f 2$ & Sig. \\
\hline 2.000 & 4 & 23 & .128 \\
\hline
\end{tabular}

Sumber: Olahan Data Penelitian 2020, Lampiran 7 halaman 41

Berdasarkan dari tabel diatas diperoleh nilai Asymp Sig 0,128yang berarti lebih besar dari 0,05 maka Ho diterima. Sehingga dapat disimpulkan bahwa kedua kelompok homogen atau mempunyai varians yang sama.

\section{Uji Normalitas}

Uji normalitas dilakukan untuk menentukan apakah sebaran data berdistribusi normal atau tidak. Penelitian menggunakan uji normalitas dengan cara Kolmogrof (uji K-S sample) pada SPSS 23. Hasil dari uji normalitas dapat dilihat dari tabel berikut:

Tabel 7 Uji Normalitas

One-Sample Kolmogorov-Smirnov Test

\begin{tabular}{llll} 
& & Kandung & Bukan Kandung \\
\hline$N$ & & 30 & 30 \\
Normal & Mean & 80.17 & 73.67 \\
Parameters & Std. Deviation & 6.757 & 7.871 \\
Most Extreme & Absolute & .157 & .146 \\
Differences & Positive & .143 & .146 \\
& Negative & -.157 & -.121 \\
Test Statistic & & .157 & .146 \\
Asymp. Sig. (2-tailed) & $.058^{\mathrm{c}}$ & $.102^{\mathrm{c}}$ \\
\hline
\end{tabular}

Sumber: Olahan Data Penelitian 2020, Lampiran 8 halaman 42

Data dikatakan normal jika tingkat Sig. Pada Kolmogrov-Smirnov lebih besar dari 0,05 maka data didistribusikan normal, jika kurang dari 0,05 maka data didistribusikan tidak normal. Nilai Sig. Orang tua kandung sebesar 0,058dan nilai Sig. Bukan Kandungsebesar 0,102. Nilai tersebut menunjukkan bahwa Sig. $>0,05$ maka Ho diterima, data tersebut berdistribusi normal.

\section{Uji Hipotesis}

Uji hipotesis dalam penelitian ini menggunakan metode t-tes untuk melihat kemampuan bahasa anak yang diasuh oleh orang tua kandung dan yang diasuh oleh selain orang tua kandung. kemampuan bahasa dua kelompok anak dikatakan berbeda secara signifikan jika Sig. $<0,05$.Jika Sig. $<0,05$ maka Ho ditolak, Ha diterima

Tabel 8 Uji Hipotesis

\section{Independent Samples Test}

Levene's Test
for Equality
of Variances t-test for Equality of Means

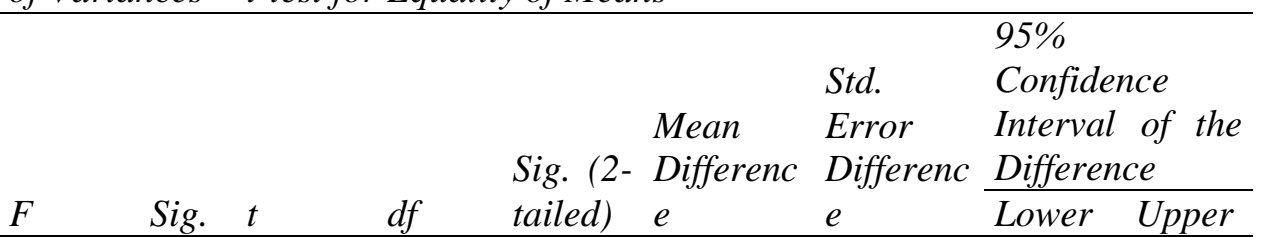


Jurnal JRPP, Volume 3 Nomor 2, Desember 2020| 196

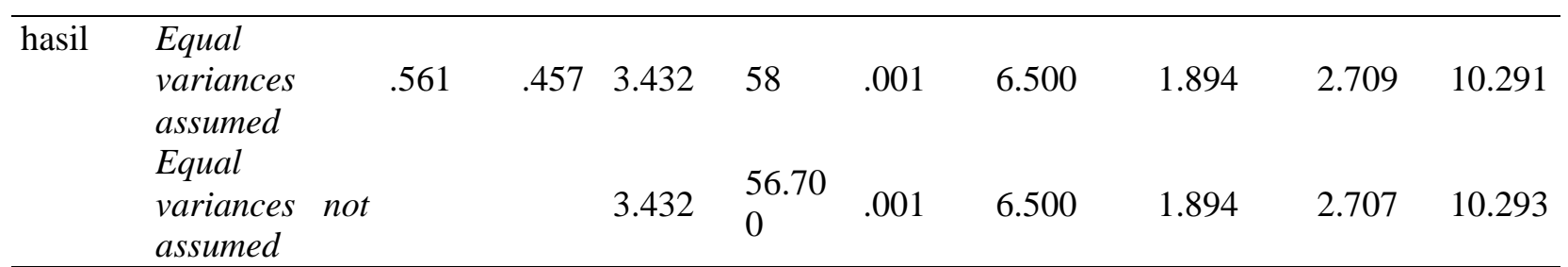

Sumber: Olahan Data Penelitian 2020, Lampiran 9 halaman 43

Berdasarkan hasil uji menggunakan Independent samplet-test, diperoleh nilai $0,001<0,05$. Maka dapat disimpulkan bahwa terdapat perbedaan signifikan kemampuan bahasa anak antara yang diasuh oleh orang tua kandung dan yang diasuh oleh selain orang tua kandung.

\section{B. PEMBAHASAN}

Perkembangan bahasa anak dapat dipengaruhi oleh beberapa faktor diantaranya interaksi orang tua dengan anak serta pola asuh didalamnya merupakan faktor paling penting dalam proses tumbuh kembang anak. Oleh karena itu, sangat diperlukan stimulus yang baik dan sesuai kebutuhan anak. Stimulus tersebut dapat diberikan orang tua ataupun selain orang tua dalam mempengaruhi perkembangan bahasa anak.

Pengambilan data yang dilakukan peneliti yaitu kuesioner/angket. Adapun pelaksanaan penelitian menggunakan angket ini memberi berbagai manfaat bagi orang tua/wali murid yang berkaitan dengan kemampuan orang tua/wali memahami anak, peningkatan pembelajaran dan pelayanan pendidikan sesuai dengan kebutuhan masing-masing anak. Dalam hal ini, angket digunakan peneliti untuk menilai kemampuan bahasa anak yang diasuh oleh orang tua kandund dan anak yang diasuh oleh selain orang tua kandung.

Berdasarkan analisis pengelolaan data dan hasil persentase di atas dapat dilihat hasil kemampuan bahasa anak usia 4-5 Tahun yang diasuh oleh orang tua kandungdi Kota Bukittinggidiperoleh jumlah nilai 481 dengan rata-rata persentase $80,17 \%$. skor akhir tertinggi terdapat pada indikator 3 yaitu anak mampumenyebutkan kata-kata yang dikenaldengan skor 101 persentase 84,17\% berada pada kriteria berkembang sangat baik (BSB). Skor akhir terendah terdapat pada indikator 2 yaitu anak mampu mengungkap perasaan dengan kata sifat (baik, senang, nakal, pelit, baik hati, berani, baik, jelek, dsb)dengan skor 93 persentase 77,50\% berada pada kriteria berkembang sesuai harapan (BSH).

Untuk melihat kondisi subjek secara keseluruhan, peneliti mengelompokkan subjek ke dalam empat kategori yaituberkembang sangat baik, berkembang sesuai harapan, mulai berkembang dan belum berkembang.Jika dilihat dari perorangan,tidak ada anak yang berada pada kriteria belum berkembang (BB) dan mulai berkembang (MB), anak yang berada pada kriteria berkembang sesuai harapan (BSH) sebanyak 10 anak dengan persentase 33,33\% dan anak yang berada pada berkembang sesuai harapan (BSB) sebanyak 20 anak dengan presentase $66,67 \%$.Berdasarkan data di atas artinya kemampuan bahasa anak yang diasuh oleh orang tua kandung berada pada kriteria berkembang sangat baik.

Berdasarkan kuesioner anak yang diasuh oleh orang tua kandung, pada indikator "Mengulang kalimat sederhana" diperoleh skor 99 atau 82,50\% dari yang diharapkan. Artinya, pada indikator pertama pencapainnya sangat baik. Pada indikator "Mengungkap perasaan dengan kata sifat (Baik, senang, nakal, pelit, baik hati, berani, baik, jelek, dsb)" diperoleh skor 93 atau 77,50\% dari yang diharapkan. Artinya, pada indikator kedua pencapainnya sangat baik. Selanjutnya, pada indikator "Menyebutkan kata-kata yang dikenal" diperoleh skor 101 atau $84,17 \%$ dari yang diharapkan. Artinya, indikator ketiga pencapainnya sangat baik.

Pada indikator "Menceritakan kembali cerita yang pernah didengar" diperoleh skor 94 atau $78,33 \%$ dari yang diharapkan. Artinya, indikator keempat pencapainnya sangat baik. Selanjutnya pada indikator "anak mampu memperkaya pembendaharaan kata" diperoleh skor 94 atau 78,33\% dari yang diharapkan. Artinya, indikator kedelapan pencapainnya sangat baik.

Berdasarkan analisis pengelolaan data dan hasil persentase di atas dapat dilihat hasil kemampuan bahasa anak usia 4-5 Tahun yang diasuh oleh selain orang tua kandung di Kota Bukittinggi diperoleh jumlah nilai 442 dengan rata-rata persentase $73,60 \%$. skor akhir tertinggi 
terdapat pada indikator 9 yaitu anak mampumenambah pembendaharaan kata dengan skor 91 persentase $75,83 \%$ berada pada kriteria berkembang sangat baik (BSB). Skor akhir terendah terdapat pada indikator 3yaitu anak mampu menceritakan cerita yang pernah didengar dengan skor 86 persentase $71,67 \%$ berada pada kriteria berkembang sesuai harapan (BSH).

Untuk melihat kondisi subjek secara keseluruhan, peneliti mengelompokkan subjek ke dalam empat kategori yaitu berkembang sangat baik, berkembang sesuai harapan, mulai berkembang dan belum berkembang. Jika dilihat dari perorangan, tidak ada anak yang berada pada kriteria belum berkembang (BB) dan mulai berkembang, anak yang berada pada kriteria berkembang sesuai harapan (BSH) 21 anak dengan persentase $70 \%$ dan anak yang berada pada kriteria berkembang sangat baik (BSB) 9 anak dengan persentase 30\%.Berdasarkan data di atas artinya kemampuan bahasa anak yang diasuh oleh orang tua kandung berada pada kriteria berkembang sesuai harapan.

Berdasarkan kuesioner anak yang diasuh oleh orang tua kandung, pada indikator "Mengulang kalimat sederhana" diperoleh skor 89 atau 74,17\% dari yang diharapkan. Artinya, pada indikator pertama pencapainnya sudah baik. Pada indikator "Mengungkap perasaan dengan kata sifat (Baik, senang, nakal, pelit, baik hati, berani, baik, jelek, dsb)" diperoleh skor 87 atau 72,50\% dari yang diharapkan. Artinya, pada indikator kedua pencapainnya sudah baik. Selanjutnya, pada indikator "Menyebutkan kata-kata yang dikenal" diperoleh skor 86 atau $71,67 \%$ dari yang diharapkan. Artinya, indikator ketiga pencapainnya sudah baik.

Pada indikator "Menceritakan kembali cerita yang pernah didengar" diperoleh skor 89 atau $74,17 \%$ dari yang diharapkan. Artinya, indikator keempat pencapainnya sudah baik. Selanjutnya pada indikator "anak mampu memperkaya pembendaharaan kata" diperoleh skor 91 atau $75,83 \%$ dari yang diharapkan. Artinya, indikator kedelapan pencapainnya sangat baik.

Setelah mengetahui hasil analisis deskriptif, langkah selanjutnya adalah melakukan uji prasyarat atau uji asumsi yang terdiri dari uji linearitas, uji homogenitas, dan uji normalitas. Kemudian melakukan uji hipotesis menggunakan independent sample t-test dengan bantuan IBM SPSS Versi 23.

Hasil pengujian linearitas data kemampuan bahasa anak yang diasuh oleh orang tua kandung dan anak yang diasuh oleh selain orang tua kandungdiketahui nilai Sig. deviation from linearity sebesar $1,148>0,05$. Sehingga dapat disimpulkan bahwa hubungan antara anak yang diasuh oleh orang tua kandung dan anak yang diasuh oleh selain orang tua kandungadalah linear.

Berdasarkan dari tabel diatas diperoleh nilai Asymp Sig0,128yang berarti lebih besar dari 0,05 maka Ho diterima. Sehingga dapat disimpulkan bahwa kedua kelompok homogen atau mempunyai varians yang sama.Data dikatakan normal jika tingkat Sig. Pada KolmogrovSmirnov lebih besar dari 0,05 maka data didistribusikan normal, jika kurang dari 0,05 maka data didistribusikan tidak normal. Nilai Sig. Orang tua kandung sebesar 0,058dan nilai Sig. Orang lain sebesar 0,102. Nilai tersebut menunjukkan bahwa Sig.>0,05 maka Ho diterima, data tersebut berdistribusi normal.

Penelitian komparatif ini dilakukan untuk mengetahui adanya perbedaan signifikan antara anak yang diasuh oleh orang tua kandung dan anak yang diasuh oleh selain orang tua kandung.Berdasarkan hasil uji menggunakan Independent samplet-test, diperoleh nilai $0,001<$ 0,05 . Maka dapat disimpulkan bahwa terdapat perbedaan signifikan kemampuan bahasa anak yang diasuh oleh orang tua kandung dan yang diasuh oleh selain orang tua kandung.

Berdasarkan jurnal penelitian yang dilakukan oleh Aisah Nur Rahmawati, Yudianto Sujana, dan Muh. Munif Syamsuddin dijelaskan bahwa Anak dari ibu pekerja paruh waktu memiliki kemampuan bahasa paling baik dibandingkan dengan anak dari ibu lainnya. Hasil penelitian menunjukkan anak dari ibu pekerja sehari penuh mempunyai kemungkinan untuk memiliki bahasa lisan 3,32 kali lebih baik daripada anak dari ibu yang tidak bekerja $(\mathrm{OR}=3,32$ dan $\mathrm{p}=0,029$ ), sedangkan anak dari ibu pekerja paruh waktu mempunyai kemungkinan untuk memiliki bahasa lisan 3,88 kali lebih baik daripada anak dari ibu yang tidak bekerja $(\mathrm{OR}=3,88$ dan $\mathrm{p}=0,026)$ dan secara simultan, status pekerjaan ibu dapat memprediksi sebesar $11,7 \%$ kemampuan bahasa lisan anak usia 4-5 tahun $(\mathrm{R} 2=0,117)$. yang berarti bahwa anak yang diasuh oleh ibu kandung/ orang tua kandung memiliki kemampuan bahasa yang lebih baik. Jika dibandingkan dengan hasil penelitian perbedaan kemampuan bahasa nak usia 4-5 tahun yang 
diasuh oleh orang tua kandung dengan anak yang diasuh oleh selain orang tua kandung, dapat disimpulkan bahwa kemampuan bahasa anak yang diasuh oleh tua kandung lebih baik daripada anak yang diasuh oelh selain orang tua kandung.

Jadi dapat disimpulkan bahwa kemampuan bahasa anak usia 4-5 tahun yang diasuh oleh orang tua kandung lebih baik dibandingkan anak yang diasuh oleh selain orang tua kandung di Kota Bukittinggi.

\section{SIMPULAN}

Berdasarkan analisis data dan pembahasan dalam penelitian ini, maka dapat ditarik kesimpulan sebagai berikut:

1. Kemampuan bahasa anak usia 4-5 tahun yang diasuh oleh orang tua kandung di Kota Bukittinggitergolong kategori berkembang sangat baik (BSB), artinya kemampuan bahasa anak usia 4-5 tahun akan berkembang sangat baik apabila diasuh oleh orang tua kandungannya

2. Kemampuan bahasa anak usia 4-5 tahun yang diasuh oleh selain orang tua kandung di Kota Bukittinggitergolong kategori berkembang sesuai harapan (BSH). Artinya anak yang diasuh oleh selain orang tua kandung hanya memiliki kemampuan bahasacukup baik.

3. Terdapat perbedaan yang signifikan kemampuan bahasa anak usia 4-5 tahun antara yang diasuh oleh orang tua kandung dan anak yang diasuh oleh selain orang tua kandung di Kota Bukittinggi.Artinya kemampuan bahasa anak usia 4-5 tahun yang diasuh oleh orang tua kandung lebih baik daripada anak yang diasuh oleh selain orang tua kandung.

\section{DAFTAR PUSTAKA}

Arikunto, Suharsimi. 2010. Prosedur Penelitian Suatu Pendekatan Praktek. Jakarta: Rineka Cipta

Arsjad, Maidar dan Mukti. 2005. Pembinaan Kemampuan Berbicara Bahasa Indonesia. Jakarta: Erlangga.

Brewer, Jo Ann. 2007. Early Childhood Education. United State Of America: Pearson

Brewer, Jo Ann. 2007. Intorduction to Early Childhood Education. USA: Pearson.

Chaer, Abdul. 2009. Pengantar Semantik Bahasa Indonesia. Jakarta: PT Rineka Cipta.

Daradjat, Zakiah. 2012. Ilmu Pendidikan Islam. Jakarta: Bumi Aksara

Depdiknas. 2004. Kurikulum Taman kanak-kanak (TK) dan Raudhatul Athfal (RA). Jakarta: Direktorat Jenderal Pendidikan Dasar dan Menengah.

Dewiani, Chika. 2019. Perbedaan Kemampuan Bahasa Anak Usia Prasekolah Antara Riwayat Diasuh Oleh Orang Tua dengan Riwayat Diasuh Oleh Selain Orang Tua. Skripsi. Keperawatan, Ilmu Kesehatan, Universitas Muhammadiyah Surakarta.

Desmita. 2013. Psikologi Perkembangan. Bandung: Remaja Rosdakarya

Fakhry Zamzam. 2018. Aplikasi Metodologi Penelitian. Yogyakarta: Budi Utama.

Feeney, Stephanie. Christensen Doris. Eva Moravcik. 2006. Who Am I in The Lives of Children. New Jersey: Pearson.

Krogh, Suzanne L. Pamela Morehouse. 2014. The Early Childhood Curriculum. New York: Routledge.

Mansur. 2005. Pendidikan Anak Usia Dini Dalam Islam. Yogyakarta: Pustaka Pelajar.

Peraturan Menteri Pendidikan dan Kebudayaan RI. Standar Nasional Pendidikan Anak Usia Dini.

Putu Ade Andre Payadnya, dkk. 2018. Panduan Penelitian Eksperimen Beserta Analisis Statistik dengan SPSS. Yogyakarta: Budi Utama.

Rahmawati, Aisyah Nur, Yudianto Sujana, Muh. Munif Syamsudin. 2016. "Status Pekerjaan Ibu Sebagai Prediktor Kemampuan Bahasa Lisan Anak Usia 4-5 Tahun". E-Jurnal.

Sugiyono. 2010. Metode Penelitian Kuantitatif, Kualitatif, dan R\&D. Bandung: Alfabeta.

Sugiyono. 2012. Metode Penelitian Kuantitatif, Kualitatif, dan R\&D. Bandung: Alfabeta.

Sugiyono. 2016. Metode Penelitian Pendidikan. Bandung: Alfabeta.

Suharsimi Arikunto. 2011. Dasar-Dasar Evaluasi Pendidikan. Jakarta: Bumi Aksara.

Sukardi. 2011. Metodologi Penelitian Pendidikan. Jakarta: Bumi Aksara 
Susanto. 2011. Perkembangan Anak Usia Dini Pengantar Dalam Berbagai Aspeknya .Jakarta: PT Kencana Perdana Media Group .

Suyanto. 2005. Konsep Dasar Anak Usia Dini. Jakarta: Departemen Pendidikan Nasional.

Syamsurie Carsel. 2018. Metodologi Penelitian Kesehatan dan Pendidikan. Yogyakarta: Penebar Media Pustaka.

Widjono. 2012. Bahasa Indonesia. Jakarta: Grasindo

Yudrik Jahja. 2011. Psikologi Perkembangan. Jakarta: Kencana.

Zubaidah, Enny. 2004. Perkembangan Bahasa Anak Usia Dini dan Teknik Pengembangan di Sekolah. 